Journal of Development and Communication Studies

Vol. 4. No. 1, January-June, 2015. ISSN (Online \& Print): 2305-7432.

bttp:/ / www.devcomsjournalmw.org

(C) Journal of Development and Communication Studies, 2015.

\title{
Integrating radio and e-media in national agricultural policy: the case of agricultural extension and advisory services in Malawi
}

\section{Levi Zeleza Manda (PhD)}

Department of Journalism and Media Studies, The Polytechnic, University of Malawi:

Email: Imanda@poly.ac.mw

\&

Rex Chapota

Farm Radio Trust, Lilongwe, Malawi. Email: rchapota@farmradiomw.org

\begin{abstract}
This paper argues that, if both the existing and potential Information Communication Technologies (ICTs), that include radio and e-media services and providers of the same (radio production studios, private, public and community radio stations, telecentres, mobile phones, and internet-resident platforms), were properly engaged and mainstreamed into the National Agriculture Policy (NAP) as a key tool for the improvement and widening of agricultural extension and advisory services, agricultural production, processing, and marketing would tremendously improve (quantitatively and qualitatively) and change the fortunes of the smallholder farmer and improve the national economy. The paper identifies nine (9) issues, which the Farm Radio Trust proposes should be integrated into the Malawi National Agriculture Policy for radio and ICTs to help improve agricultural extension services in Malawi.
\end{abstract}

Key terms: agricultural policy, e-media, extension policy, ICT4D, C4D, radio for development

Cite this article as: Manda, LZ \& Chapota, R. 2015, Integrating radio and e-media in national agricultural policy: the case of agricultural extension and advisory services in Malawi, Journal of Development and Communication Studies, 4(1):49-61 DOI: http://dx.doi.org/10.4314/jdcs.v4i1.4 


\section{Introduction}

\section{The role of agricultural extension in agriculture development}

The agriculture sector in Malawi is divided into two main sectors of estate and smallholder farming. The smallholder sector that is predominantly rural and contributes more than 70 percent to the food security needs and economic growth of the country (Malawi Government, 2008). Official statistics indicate that agriculture remains the backbone of Malawi's economy, contributing 39\% to GDP, bringing into the country $80 \%$ of foreign exchange earnings, and employing some 80\% of Malawians (Malawi Government, 2011). According to the FAO, (2003), concentration on small farmers leads to faster growth rates of both economic output and employment. However, in order to reach small holder farmers effectively, there is a need for innovative strategies in agricultural extension. Anderson (2007: .6) defines the term agricultural extension services as "the entire set of organisations that support and facilitate people engaged in agricultural production to solve problems and to obtain information, skills and technologies to improve their livelihoods" whilst Christoplos (2010:2) defines agricultural extension as "all the different activities that provide the information and advisory services that are needed and demanded by farmers and other actors in agrifood systems and rural development". Thus, modern extension is complex and departs from its traditional counterpart, which was obsessed with top-down sender-receiver (S-R) transfer of technology and knowledge as an agricultural modernising intervention from researcher to farmers. Today's extension is grounded in social change and participatory communication for development (C4D), which also informs Information and Communication Technologies and Services for Development (ICT4D) (see Rogers, 1976; Besette, 2004; Freire, 1996; Figueroa et al., 2002).

The agricultural extension and advisory service system plays a crucial role in this respect since it drives agricultural productivity and ensures that smallholder farmers who are in the majority in Malawi are reached with information and appropriate knowledge on relevant technologies that can facilitate improved agricultural yields. This, in turn, is vital in stimulating growth in other parts of the economy although accelerated growth requires a sharp productivity increase in smallholder farming and effective support to the millions coping as subsistence farmers (World Bank, 2008). To this end, African Heads of State and Government in the Common Market for East and Southern Africa (COMESA) region signed the Comprehensive African Agriculture Development Programme (CAADP) that recognizes the importance of research, technology generation, and dissemination through agricultural extension and advisory services as prime movers of agricultural development in order to put agriculture on the path of sustainable growth (Malawi Government, 2010). The Malawi Government has recognized that the success of increased agricultural production programs will depend, to a large extent, on appropriate technologies being developed, disseminated and used by farmers of both gender categories and all social strata (Malawi Government, 2010).

Agricultural extension and advisory services play an important role in improving farm yields and can contribute to uplifting the welfare of farmers and other people living in rural areas; hence, the need for this critical service to be profiled in the National Agricultural Policy. 


\section{Agricultural extension and advisory services through radio enhanced by ICTs}

Individual, group and mass media agricultural extension and advisory services have been used concurrently over time. Radio, in particular, as one of the traditional Information Communication and Technologies (ICTs) has dominated agricultural extension. In Malawi, the continuing increase in the number of farm families led to the Malawi government's emphasis on approaches that reach a large clientele at a time. This marked the genesis of the then Public Relations Unit (PRU), currently known as the Agricultural Communications Branch (ACB), that was established in 1958 to complement the efforts of extension and training service programs. Typical of modernisation approaches and development media, the Unit focused its attention on providing technical messages to the farming community through the radio supported by producing and distributing print material. The Agricultural Communications Branch has continued to provide mass media agricultural extension and advisory services, primarily through radio (Kabuye and Mhango, 2006).

The environment for use of radio for extension and advisory services has evolved over time in terms of the policies, laws, approaches and players involved. Prior to 1994, broadcasting was the monopoly of the state; hence, most, if not, all agricultural extension and advisory services radio programs were being aired on the national radio, Malawi Broadcasting Corporation (MBC). The re-introduction of multiparty democracy in 1994 led to the opening up of the airwaves thereby increasing the number of radio stations especially FM commercial and community radio stations, whose radio programming is participative and people-centred. Radio broadcasting regulation falls within the Malawi Information Communication Technology (ICT) Policy of 2006. The ICT Policy aims at "facilitating the creation of an enabling environment for efficient, effective and sustainable utilisation, exploitation and development of ICTs in all sectors of the economy in order to attain an information rich and knowledge based society and economy" (Malawi Government, 2006).

The rationale of using radio in extension and advisory services emanates from an understanding that radio is an excellent, cost-effective means of sharing knowledge, building awareness, facilitating informed decision-making and supporting the adoption of new practices by small-scale farmers (FRI, 2007). The fact that the Malawi national population and household census report of 2008 indicates that nationally $64.1 \%$ of households own radios, up from $49.9 \%$ in 1998 , signifies that radio gives an opportunity for the agricultural extension and advisory service system to reach a wider audience. Radio regularly reaches $70 \%$ of rural households; it is affordable, it is accessible to the illiterate, it can use local languages and it can give voice to end-users (FRI, 2011). Currently, Malawi, like other African countries, is experiencing a mobile telephone boom with some surveys reporting off-grid subscription of about 3 million for Malawi's population of 12 million (TNM 2013). The new ICT Policy of 2013 notes that the Millennium Development Goals (MDG) report of 2011 for Malawi indicated that use of Internet by the population in Malawi improved from the low levels of 0.07 percent in 2005 to 17 percent in 2011 whilst tele-density (the use of mobile and fixed telephones) has improved from 2.63 percent to about 27 percent in the same period. This is largely due to the increase in the use of mobile telephones (Malawi Government, 2013).

\section{Why radio deserves prominence in agricultural policy}

A cursory literature review indicates that various forms of media have been consistently employed to support agricultural extension and advisory services in Malawi for nearly 60 years. 
Tracing the evolution of agricultural extension in Malawi, Kabuye and Mhango (2006), Masangano and Mthinda (2012,) and Chapota et al. (2014) have identified the use of mobile cinema vans for mass mobilization and outreach programmes, face-to-face trainings, on-farm demonstrations, agricultural fairs and shows, training and visits, posters, magazines, and leaflets, and public service radio, participatory ICT enhanced radio programming, as some of the media that have been deployed to disseminate information to farmers. Radio, in particular, has been used without interruption since 1958 (Malindi, 2009; Chimgonda-Nkhoma, 2009; Chowa, 2009). Radio has featured prominently because most of Malawi's smallholder farmers are illiterate and heavily rely on the oral and aural communication media. Since 1999, when Malawi established its own TV station, agricultural extension has also been broadcast to farmers' homes through television. Other studies (Farm Radio International, 2011; MOST, 2014) suggest that combining radio with internet-based media platforms and using interactive radio formats, such as call-ins and call-outs, SMS, and participatory video, can make Malawi's agricultural extension cheaper but more effective as it encourages participation and information sharing.

The African Farm Radio Research Initiative (AFRRI) project implemented in five African countries of Malawi, Tanzania, Mali, Uganda and Ghana demonstrated that if a more participatory approach is adopted and radio is supported by ICTs, such as telephones, radio can be the "midas touch" for agricultural extension in Africa (Farm Radio International, 2011). Therefore, radio enhanced by new Information Communication Technologies (ICTs), such as mobile phones, offers an inclusive, personable and multi-dimensional communication platform that extends the reach and impact of broadcasts. The Farm Radio International (FRI) experience shows that with strong linkages in both the communication and agricultural sector, it is possible for broadcasters to produce impactful radio broadcasts enhanced by ICTs such as phone-in shows, facilitate and record community discussions and debates, document the experiences of individual farmers and other value chain actors, pose farmers' questions to subject matter specialists, and link sellers with buyers on air (FRI, 2011). As a result of these features, ICT enhanced radio may be highly effective and efficient - particularly when compared with the per-farmer cost of face-to-face extension service with the current untenable extension workerto-farmer ratio of one extension worker to more than 1500 smallholder farmers in Malawi (DAES, 2011). FRI through a study under the African Farm Radio Research Initiative (AFRRI) concluded that ICTs have changed the face of radio programming. For example, the study found that weekly SMS alerts sent 30 minutes prior to a broadcast increased listenership by up to $20 \%$; farmers participation in radio programming through ICTs were four times more likely than those in passive listening communities to adopt agricultural improvements promoted on the radio and that $61 \%$ of extension agents noted that mobile call-outs in a radio show had extended their reach and impact (FRI, 2011).

Over time, radio programming, as an extension and advisory service approach, has proved its power to improve farmers' decision-making by providing them with relevant information and sharpening their analytical perspectives as they undertake decisions that lead to improved farm management, yields, nutrition and food security (Manyozo, 2009). The challenge is to understand and explore how radio, enhanced by ICTs, is contributing to agricultural knowledge exchange in the context of agricultural extension and advisory services models. In general, ICTs and ICT services, have been found to spur sustainable development and reduce poverty in Africa and the developing world (Dagron, 2001, 2003; Ilboudo and del Castello, 2003; May et al., 2014).

Therefore, the agricultural policy should consider investing in ICT-enhanced participatory radio that respects locally-prized formats and local languages. Local community radio stations are highly recommended as a unique place for the production and broadcasting location and crop-specific radio programming.

In 2011, the Millennium Development Goals Report for Malawi (cited in Malawi Government, 2013) noted an exponential increase in the ownership and use of the internet and 
mobile phones. It indicated that from 2005 to 2011, use of the internet had increased from $0.07 \%$ to $17 \%$ while mobile phone usage had gone from $2.23 \%$ to $27 \%$. This shows the potential of mobile phones and telecentres as tools for reaching farmers with agricultural messages. In partnership with mobile telephone providers, such as TNM and Airtel, SMS can be used to inform farmers about prices, weather patterns, markets, new seeds, cultural practices, nutrition and education. Thus, the agricultural policy in Malawi ought to consider the critical role of e-media platforms such as SMS and internet video, among others.

Already, a number of a number of organisations, including the Ministry of Agriculture, are combining radio programming with mobile and internet-based platforms, stand-alone videos shows, and TV to support agricultural extension (see Table 1).

\section{Table 1: Type of electronic media currently being used}

\begin{tabular}{|c|c|c|c|c|c|}
\hline \multirow{2}{*}{$\begin{array}{l}\text { Name of extension } \\
\text { service provider }\end{array}$} & \multicolumn{5}{|c|}{ Type of electronic media currently being used } \\
\hline & Radio & $\begin{array}{l}\text { Mobile } \\
\text { Phones }\end{array}$ & Television & Internet & Videos \\
\hline MoAIW-DAES & $\begin{array}{l}\text { Agricultural } \\
\text { messages and } \\
\text { adverts }\end{array}$ & $\begin{array}{ll}\text { Esoko } & \\
\text { platform } & \text { SMS } \\
\text { for } & \text { lead } \\
\text { farmers } & \end{array}$ & $\begin{array}{l}\text { Documentaries } \\
\text { for specific } \\
\text { agricultural } \\
\text { projects }\end{array}$ & & $\begin{array}{l}\text { Farmer to } \\
\text { farmer } \\
\text { DVDs and } \\
\text { use of } \\
\text { mobile } \\
\text { cinema on } \\
\text { specific } \\
\text { technologi } \\
\text { es }\end{array}$ \\
\hline $\begin{array}{lr}\text { Malawi } & \text { Milk } \\
\text { Association } & \text { of } \\
\text { Malawi (MMPA) } & \end{array}$ & & $\begin{array}{l}\text { Esoko } \\
\text { platform for } \\
\text { SMS to dairy } \\
\text { farmers }\end{array}$ & & & \\
\hline NASFAM & $\begin{array}{l}\text { Agricultural } \\
\text { messages and } \\
\text { adverts on } \\
\text { markets }\end{array}$ & $\begin{array}{l}\text { SMS platforms } \\
\text { for } \\
\text { associations }\end{array}$ & & & $\begin{array}{l}\text { Farmer to } \\
\text { farmer } \\
\text { DVDs on } \\
\text { selected } \\
\text { innovation } \\
\mathrm{s}\end{array}$ \\
\hline ACE & & $\begin{array}{l}\text { Esoko } \\
\text { platform for } \\
\text { prices } \\
\text { information }\end{array}$ & & $\begin{array}{l}\text { Internet } \\
\text { platforms } \\
\text { for price } \\
\text { and trade } \\
\text { informatio } \\
\mathrm{n}\end{array}$ & \\
\hline AHCX & Adverts & $\begin{array}{l}\text { SMS platforms } \\
\text { for price } \\
\text { information }\end{array}$ & & $\begin{array}{l}\text { Internet } \\
\text { platforms } \\
\text { for price } \\
\text { and trade } \\
\text { informatio } \\
\mathrm{n}\end{array}$ & \\
\hline Story Workshop & $\begin{array}{l}\text { Agricultural } \\
\text { messages }\end{array}$ & & & & $\begin{array}{l}\text { Video } \\
\text { documenta } \\
\text { ries }\end{array}$ \\
\hline
\end{tabular}




\begin{tabular}{|c|c|c|c|c|}
\hline $\begin{array}{l}\text { Agri } \\
\text { International }\end{array}$ & & $\begin{array}{l}\text { Esoko } \\
\text { platforms for } \\
\text { lead farmers }\end{array}$ & & \\
\hline Alliance One & & $\begin{array}{l}\text { SMS platforms } \\
\text { for extension }\end{array}$ & & \\
\hline Self Help Africa & $\begin{array}{l}\text { Agricultural } \\
\text { radio } \\
\text { programs }\end{array}$ & $\begin{array}{l}\text { 3-2-1 } \\
\text { platforms- } \\
\text { SMS, Voice } \\
\text { and SSDA }\end{array}$ & & \\
\hline ARET & $\begin{array}{l}\text { Agricultural } \\
\text { radio } \\
\text { programs }\end{array}$ & & & $\begin{array}{l}\text { Video } \\
\text { documenta } \\
\text { ries }\end{array}$ \\
\hline ECRP & & $\begin{array}{l}\text { Weather SMS } \\
\text { alerts }\end{array}$ & & \\
\hline CISANET & $\begin{array}{l}\text { Policy } \\
\text { dialogue } \\
\text { sessions }\end{array}$ & & & $\begin{array}{l}\text { Video } \\
\text { documenta } \\
\text { ries, farmer } \\
\text { to farmer } \\
\text { videos }\end{array}$ \\
\hline FUM & $\begin{array}{l}\text { Agricultural } \\
\text { radio } \\
\text { programs }\end{array}$ & & News features & $\begin{array}{l}\text { Video } \\
\text { documenta } \\
\text { ries }\end{array}$ \\
\hline FRT & $\begin{array}{l}\text { Agricultural } \\
\text { messages } \\
\text { across value } \\
\text { chains }\end{array}$ & $\begin{array}{l}\text { SMS and } \\
\text { Voice } \\
\text { messages }\end{array}$ & & $\begin{array}{l}\text { Video } \\
\text { documenta } \\
\text { ries }\end{array}$ \\
\hline $\begin{array}{l}\text { MoAIW-Department } \\
\text { of Research Services }\end{array}$ & $\begin{array}{l}\text { Agricultural } \\
\text { message }\end{array}$ & & Documentaries & $\begin{array}{l}\text { Video } \\
\text { documenta } \\
\text { ries }\end{array}$ \\
\hline
\end{tabular}

Source: MOST, 2014

\section{Unique place of telecentres in agricultural extension}

Telecentres offer a unique opportunity for Malawi's agricultural extension and advisory service providers because, ideally, they house internet, email, telephone, radio, photocopying, printing and TV services under one roof. In partnership with private entrepreneurs, the Malawi Government has established over 51 telecentres across the country (see Table 2) to translate and operationalise its National ICT Policy (Malawi Government, 2013). However, studies show that in Malawi these are not being used maximally (Chikumba, 2011; Kapondera-Longwe, 2012). In most cases, the centres are frequented by people that want to photocopy or type up documents and access social media such as Facebook.

However, elsewhere in Africa, Asia, and the Americas, telecentres are used as centres for accessing agricultural information, methods, and markets. So, if the agricultural policy emphasised this function of telecentres and provided funds for popularising them, telecentres would be a very effective source of agricultural information and services.

As at January, 2014, the following telecentres had already been established and were functional. 


\begin{tabular}{|l|l|}
\hline Name of telecentre & DISTRICT \\
\hline Mulanje Telecenter & Mulanje \\
\hline Chitakale TDC Telecenter & Mulanje \\
\hline St Maria Gorreti TDC Telecenter & Nkhatabay \\
\hline Nkhatabay Telecentre & Nkhatabay \\
\hline Kasungu Telecentre & Kasungu \\
\hline Vikwa Telecenter & Kasungu \\
\hline Songani Telecenter & Zomba \\
\hline Nasawa Technical College & Zomba \\
\hline Khudze Telecenter & Mwanza \\
\hline Mpinji Telecenter & Thyolo \\
\hline Goliati Telecentre & Thyolo \\
\hline Gumbu TDC Telecenter & Ntcheu \\
\hline Mzuzu Telecenter & Mzuzu \\
\hline Chikwawa TDC Telecenter & Chikwawa \\
\hline Ching'ombe TDC Telecenter & Lilongwe \\
\hline Lupaso Telecenter & Karonga \\
\hline Dedza TCD Telecenter & Balaka \\
\hline Neno chikonde TDC Telecenter & Neno \\
\hline Dowa TDC Telecenter & Dowa \\
\hline Machinga TDC Telecenter & Machinga \\
\hline Mzimba Telecenter & Mzimba \\
\hline Salima Telecenter & Salima \\
\hline Salima Technical college & \\
\hline Chikwawa Telecenter & Soche Technical Telecenter \\
\hline
\end{tabular}




\begin{tabular}{|l|l|}
\hline Balaka Telecenter & Balaka \\
\hline Nkhotakota Telecentre & Nkhotakota \\
\hline
\end{tabular}

Source: $M A C R A, 2014$

It is clear from their geographic spread that telecentres have the potential to serve as sources of development-related information for local people throughout Malawi. The only challenge, as Eliya (2015) points out in his study of factors that prevent local urban people from accessing telecentre services, is the users' ability to pay for the services.

\section{Addressing challenges in agricultural extension}

The biggest challenge to agricultural extension and advisory service provision in Malawi relates to reduced public financial allocation to agricultural extension (Malawi Government, 2000), limited agriculture radio production and broadcasting, and to some extent, low education levels of most field-based extension officers (Agunga and Manda, 2014). This problem is compounded by the fact that government departments do not seem to be aware that the MBC is supposed to give airtime for the communication of important government services such as health and agricultural extension. Further, the MBC is obliged by its public service mandate to produce programmes whose content promotes development in Malawi. However, the MBC does not produce any substantive agricultural radio programme (only one hour per week of music request by farmers), although it broadcasts some $49 \%$ of the agricultural programmes (Manda, 2010; 2012). The programmes that the MBC broadcasts are mostly produced by private studios and community radio stations and financed by projects and NGOs working in the agriculture and environment sector, a phenomenon most African countries share (Myers, $2008 ; 2010)$.

The Malawi Agricultural Extension Policy (Malawi Government, 2000) encourages cost sharing, public-private partnerships and advocates for demand-driven and the-farmer-pays approach to extension. This policy ought to be implemented with caution to determine how much and the means through which the smallholder farmer can contribute. The National Agricultural Policy should emphasise the role of the Malawi government in devising strategies for funding agricultural extension without overburdening the poor smallholder farming community.

\section{Issues to integrate in the National Agriculture Policy (NAP)}

The Malawi Government development policy documents (notably, the Malawi Growth and Development Strategy, National ICT Policy, and Communication Policy) recognise the importance of ICT in development. In fact the National ICT Policy (Malawi Government, 2013) observes that ICT can stimulate and modernise national development sectors such as agricultural. The policy encourages the use of ICT in "agro-business industry, agricultural extension services, research in agricultural production and processing" (emphasis added).

Therefore, this paper proposes that the following issues be considered in enhancing the NAP: 
- Agricultural extension has to be incorporated in the policy on the premise that it includes other innovative forms of extension. In this case ICT-based extension services since in the past extension has been synonymous with "face to face" extension.

- Radio should be prioritized as the major support ICT medium for agricultural extension delivery since studies show that over $50 \%$ of the smallholder farmers rely on radio as a source for agricultural information since the face to face extension is currently weak and limited in numbers (MEJN, 2004; Manda, 2012).

- The policy should specifically put investment mechanism for ICT for agricultural development efforts with an emphasis on public private partnerships as a key driver in knowledge exchange in the agricultural value chains.

- Partnership with mobile telephone providers, such as TNM and Airtel, SMS should be encouraged to create a Public Service Agricultural Platform (as part of the corporate social responsibility) where farmers can access information on commodity and input prices, weather patterns, markets, new seeds and cultural practices at reasonable prices.

- Partnership with universities (public and some private) to introduce upgrading and refresher Communication for Development (C4D including use of ICTs in development) courses for serving agricultural extension staff. The new knowledge acquired will help the extension officers to authoritatively deal with farmers' questions.

- Popularisation of telecentres, video kiosks, and other outlets XXX as major sources of agricultural extension, marketing, and learning should be prioritised. Here, too, partnership with radio stations, newspapers, mobile telephone and internet providers is critical in spreading awareness about telecentre potential.

- The role of public broadcast media (Malawi Broadcasting Corporation-MBC) in agricultural extension should be fully defined in the NAP since as public broadcaster, MBC is mandated by its licence conditions to provide free public service advertisements (PSA), which can, as well, be in the form of agricultural extension messages.

- In line with the Malawi Communication Sector Policy and National ICT Policy, the NAP should include awareness on the role of Radio and ICTs in e-agriculture business.

- The Malawi National Agricultural Policy should include a framework for evaluating the impact of communication for development (C4D) interventions, such as radio for development and ICT for Development (ICT4D) so that the use of these is improved on (for more on evaluating C4D interventions, see Lennie \& Tacchi, 2013) for the benefit of the smallholder farmer and the national economy.

\section{References}

Agunga, R. \& L.Z Manda (2014)

Communication for strengthening agricultural extension and rural development in Malawi. http://ajol.info/index.php/jdcs/article/view/112348. (Accessed 17 March, 2015).

Anderson, J.R. (2007) 
Agricultural Advisory Services, Background Paper for the World Development Report 2008.http://siteresources.worldbank.org/INTWDR2008/Resources/27950871191427986785/Anderson AdvisoryServices.pdf. (Accessed 11 March, 2015).

Besette, G. (2004)

Involving the community: a guide to participatory development communication. Penang: Southbound.

Chapota, R, P. Fatch \& C. Mthinda (2014) The Role of Radio in Agricultural Extension and Advisory Services Experiences and Lessons from Farm Radio Programming in Malawi. http://www.farmradiomw.org/publications/MEAS-CS-Malawi-Farm-RadioChapota-Fatch-Mthinda-Feb-2014.pdf. (Accessed 11 March, 2015).

Chapota, R. (2009)

The Farm Radio Research Initiative-Working with Radio Stations and Smallholders farmers: Experiences and Lessons Learnt. Paper presented at the $1^{\text {st }}$ Farm Radio Symposium, Cresta Hotel, Lilongwe, $5^{\text {th }}$ August, 2009.

Chikumba, P.A. (2011)

Utilization of Information Communication Technologies in Multipurpose Community Telecentres in Rural Malawi: Opportunities and Challenges. Blantyre: Malawi Communications Regulatory Authority (MACRA).

Chim'gonda-Nkhoma, J. (2009)

Experiences and Lessons Learnt in Agricultural Extension Programming: The Case of Ministry of Agriculture and Food Security, Malawi. Paper presented at Chowa, C. (2009) the $1^{\text {st }}$ Farm Radio Symposium, Crossroads Hotel, Lilongwe.

Agricultural Extension Policy in Malawi: The Case of Farm Radio. In Khaila, S. \& C. Masangano. Proceedings Report of the $1^{\text {st }}$ Annual Farm Radio Symposium.

Lilongwe: Ministry of Agriculture (pp.22-29)

Christopolos, I. (2010)

Mobilizing the potential of rural and agricultural extension. Rome: FAO

Dagron, A.G. (2001)

Making Waves: Stories of Participatory Communication for Social Change. New York:

The Rockefeller Foundation.

Dagron, A.G. (2003)

Take Five: A handful of essentials for ICTs in development. In Grand, B.

The One to Watch: Radio, New ICTs and Interactivity. Rome: FAO. (pp. 21-38)

Eliya, V. (2015)

http://fao.org/docrep/fao/006/y4721e/y4721e00.pdf. (Accessed 1 June, 2011).

Impact of Economic status of users on pattern and kind of services accessed at

Telecentres in Malawi: A Case Study of Soche Technical College Telecentre

(Unpublished Bachelor of Arts in Journalism dissertation). Blantyre: The Polytechnic, University of Malawi

Farm Radio International (2007)

Proposal submitted to Bill and Melinda Gates Foundation on the African Farm Radio Research Initiative. Ottawa. Canada

Farm Radio International (2011) 
Participatory Radio Campaigns and Food Security: How Radio Can Help Farmers Make Informed Decisions. Ottawa: Farm Radio International.

http://www.farmradiomw.org/publications/MEAS-CS-Malawi-Farm-RadioChapota-Fatch-Mthinda-Feb-2014.pdf. (Accessed 11 March, 2015)

Figueroa, M.E., D.L. Kincaid, M. Rani, \& G. Lewis (2002)

Communication for Social Change: An Integrated Model for Measuring the Process and Its Outcomes. The Communication for Social Change Working Paper Series: No.1. New York: Johns Hopkins University's Center for Communication Programs/Rockefeller Foundation.

Freire, P. 1996.

The Pedagogy of the Oppressed. London: Penguin Books.

Ilboudo, J-P. \& del Castello, R. (2003)

Linking Rural Radio to New ICTs in Africa: Bridging the rural digital divide. In Grand, B. The One to Watch: Radio, New ICTs and Interactivity. Rome: FAO. (pp 39-56). bttp:/ / www.fao.org/docrep/006/y4721e/y4721e06.btm\#bm06. (Accessed 2 February, 2015).

Kabuye, E.S. \& J.A. Mhango, (2006)

A Brief History of Agricultural Extension Services in Malawi from 1948 to 2000.

Lilongwe: Ministry of Agriculture.

Kapondera-Longwe, S.K. (2012)

An Exploratory Study of the Role of Telecentres in Providing Community Access to Information and Communication Technology in Malawi: A case Study of Goliati Telecentre. Malawi Journal of Library and Information Science, 1(1):1-18

Lennie, J \& J. Tacchi (2013)

Evaluating Communication for Development: A framework for social change. London:

Earthscan-Routledge.

Malawi Communication Regulatory Authority (2014)

Telecenter Contacts. Blantyre: Malawi Communication Regulatory Authority (MACRA)

Malawi Economic Justice Network (MEJN) (2004)

Findings of Service Delivery Satisfaction Survey II. Lilongwe: MEJN.

Malawi Government (2006)

Malawi Growth and Development Strategy, Volume I. Lilongwe: Ministry of

Economic Planning

Malawi Government (2008)

The Agricultural Development Programme (ADP) Malawi's prioritised and harmonized

Agricultural development agenda: 2008 -2012. Ministry of Agriculture and Food

Security.

Malawi Government (2010)

Malawi CAADP Compact to support the successful implementation of agriculture sector wide approach. Lilongwe. Malawi

Malawi Government (2010)

The Agriculture Sector Wide Approach (ASW Ap). Malawi's prioritised and harmonised Agricultural Development Agenda. Lilongwe: Ministry of Agriculture and Food Security

Malawi Government (2000) 
Agricultural Extension in the New Millennium: Towards Pluralistic and Demand-driven

Services in Malawi. Lilongwe: Ministry of Agriculture.

Malawi Government (2011)

Malawi Agricultural Sector Wide Approach - A Prioritised and Harmonised Agricultural

Development Agenda: 2011-2015. Lilongwe: Ministry of Agriculture and Food

Security.

Malawi Government(2013),

National ICT Policy: An ICT-Led Malawi. Lilongwe: Ministry of Information

Malawi Oilseeds Transformation (2014)

Electronic Media Services in Malawi (Unpublished Research Report). Lilongwe:

Malawi Oilseeds Transformation (MOST).

Malindi, G. (2009)

The Agricultural Extension Service Policy: Role of Radio as Part of the

Agricultural Extension Methodologies. Paper presented at a Farm Radio

Symposium, Crossroads Hotel, Lilongwe.

Manda, L.Z. (2010)

Development Programming in Public Service Broadcasting in Malawi: A

content analysis of MBC Radio 1 and Television Malawi (Unpublished study

report)Lusaka: PANOS Southern Africa.

Manda, L.Z. (2012)

Farm Radio Services in Malawi. Saarbrucken (Germany): Lambert Academic

Publishers.

Manyozo, L. (2009)

Communicating with Radio: What do we know, findings from a review of selected rural radio

Manyozo, L. (2012)

effectiveness evaluations. Farm Radio International.

People's Radio: Communicating Change Across Africa. Penang: Southbound.

Masangano, C. \& C. Mthinda. (2012)

Pluralistic Extension Service in Malawi. IFPRI Discussion paper No. 01171.

The International Food Policy Research Institute (IFPRI).

http:// www.ifpri.org/sites/default/files/publications/ifpridp01171.pdf.

(Accessed 12 October. 2012).

May, J. T.M. Waema, \& E. Bjåstad (2014)

Introduction: The ICT/poverty nexus in Africa. In Adera, E.O., T.M. Waema,

J. May, O. Mascarenhas, \& K.Diga (eds.) ICT Pathways to Poverty Reduction

Empirical evidence from East and Southern Africa.

http://www.idrc.ca/EN/Resources/Publications/openebooks/539_

7/index.html\#ch01. (Accessed 25 March, 2015).

Myers, M. (2010).

Why radio matters: Making the Case for Radio as a Medium for

Development.

http://developingradio.org/files/Why $\% 20$ Radio $\% 20$ Matters $\% 20$ Mary $\% 20$ Mye

rs\%20DRP.pdf (Accessed 19 August, 2012).

Myers, M. (2008).

Radio and Development in Africa: A Concept Paper.

http://www.dfid.gov.uk/r4d/PDF/Outputs/ICT4D/Radio and Developmen

$t$ in Africa concept paper.pdf. (Accessed 19 August, 2012).

Pearson, M. (2010) 
DFID Malawi Impact Evaluation of the SWAp: Final Report. London: DfID http://www.dfid.gov.uk/Documents/publications1/hdrc/imp-eval-sect-wdeappr-mw.pdf. (Accessed 15 October, 2012).

Rivera, W.M with M.K. Qamar (2003) Agricultural Extension, Rural Development and the Food Security Challenge. http://www.fao.org/docrep/006/Y5061E/Y5061E00.HTM. (Accessed 20 March, 2015).

Rogers, E. (1976)

Communication and development : the passing of the dominant paradigm. In

Schramm, W. (ed.), Communication and development: critical perspectives (pp. 121-148). London: SAGE.

Telecom Networks Malawi (TNM). 2013

TNM-Malawi Feasibility Study. http://www.gsma.com/mobilefordevelopment/wpcontent/uploads/2013/02/TNM-Feasibility-Study.pdf . (Accessed 5 June 2015)

$\operatorname{UNDP}(2007)$

Information Note on the One Budgetary Framework and One UN Fund. http://www.undg.org/index.cfm?P=1209. (Accessed 30 November, 2012).

UNOCHA (2012)

Annual Report: The Democratic Republic of the Congo.

http://www.unocha.org/drc/financing/common-humanitarian-fund. (Accessed 3 December, 2012).

World Bank (2008).

World Development Report 2008: Agriculture for Development, World Bank, Washington, D.C. http://siteresources.worldbank.org/INTWDR2008/Resources/WDR 00 boo k.pdf. (Accessed 11 March, 2015). 